ISSN 0103-5150

Fisioter. Mov., Curitiba, v. 28, n. 2, p. 365-372, Apr./June 2015

Licenciado sob uma Licença Creative Commons http://dx.doi.org.10.1590/0103-5150.028.002.A017

\title{
Effectiveness of a physical activity program on indicators of health status of users of the Family Health Strategy
}

\section{Efetividade de um programa de atividade física nos indicadores do estado de saúde de usuários da Estratégia de Saúde da Família}

\section{Janaina Vasconcelos Rocha ${ }^{[a]}$, Saulo Vasconcelos Rocha ${ }^{[b]}$, Wisla Keile Medeiros Rodrigues ${ }^{[b]}$, Paulo Fonseca Valença Neto ${ }^{[b]}$, Lélia Renata Carneiro Vasconcelos ${ }^{[b] *}$}

[a] União Metropolitana de Educação e Cultura (Unime), Ibicuí, BA, Brazil

[b] Universidade Estadual do Sudoeste da Bahia, Jequié, BA, Brazil

\begin{abstract}
Introduction: The guided interventions in drug therapies contribute to the effectiveness of health promotion in the Family Health Strategy (FHS). Objective: To evaluate the effectiveness of an action grounded in physical activity in heath state of users in the Unified Health System [Sistema Único de Saúde - SUS] of the Family Health Strategy of the Municipality of Iguaí (BA). Methodology: Intervention study with an epidemiological approach, studies in the community, sample of 30 registered users on FHU aged $\geq 60$ years old. Data collection was performed using an instrument that contained sociodemographic information, and evaluation of blood

* JVR: grad., specialist in Public Health Management with emphasis in Family Health, e-mail: enferjana@hotmail.com SVR: MSc, e-mail: svrocha@uesb.edu.br WKMR: grad., e-mail: wislakmr@hotmail.com PFVN: MSc, e-mail: paulonetofonseca@hotmail.com LRCV: MSc, e-mail: renatavcarneiro@gmail.com
\end{abstract}


pressure and glucose levels, weight and height for later calculation of Body Mass Index (BMI). The physical activity program was conducted during the period of 10 months, with a frequency of 5 days/weeks. The activities were carried out in a city of FHU of Iguaí (BA). The data from this study were tabulated and analyzed using SPSS 15.0. Results: After the intervention, there was a statistically significant reduction in levels in the blood pressure and glucose levels, and reduction in body mass index, indicating the importance of this intervention as a form of non-pharmacological treatment for hypertension and diabetes. Conclusion: We observed the effectiveness of the intervention was possible to reduce risk factors, but it is necessary that the projects have sustainability, to continue with its development.

Keywords: Physical activity. Health promotion. Intervention studies. SUS.

\section{Resumo}

Introdução: As intervenções pautadas em terapias não medicamentosas contribuem para a efetivação da promoção da saúde na Estratégia de Saúde da Família (ESF). Objetivo: Analisar a efetividade de uma ação pautada em práticas de atividades físicas no âmbito do Sistema Único de Saúde (SUS) no estado de saúde de usuários da ESF do município de Iguaí (BA). Metodologia: Estudo de intervenção com uma abordagem epidemiológica, na modalidade estudos comunitários, amostra composta por 30 usuários cadastrados na Unidade de Saúde da Família (USF) com idade $\geq 60$ anos. A coleta de dados foi realizada por meio de um instrumento que continha informações sociodemograficas, além de avaliação dos índices pressóricos e glicêmicos, peso e estatura para posterior cálculo do Índice de Massa Corporal (IMC). O programa de atividade física foi conduzido durante o período de 10 meses, com frequência de 5 dias/semana. As atividades eram realizadas no espaço do de uma USF no município de Iguaí (BA). Os dados do presente estudo foram tabulados e analisados por meio do Programa SPSS 15.0. Resultados: Após a intervenção observou-se uma redução em níveis estatisticamente significante nos índices pressóricos e glicêmicos, além de redução no IMC, evidenciando a importância dessa intervenção como modalidade de tratamento não medicamentoso para hipertensão e diabetes. Conclusão: Observou-se a efetividade da intervenção e foi possível reduzir indicadores de risco, porém é necessário que os projetos tenham sustentabilidade, para que prossigam com o seu desenvolvimento.

Palavras-chave: Atividade física. Promoção da saúde. Estudos de intervenção. SUS.

\section{Introduction}

The World Health Organization (WHO) (1) highlights that the main causes of mortality in the country are cardiovascular disease, followed by cancer, external causes and homicides. In the city of Iguaí (BA), in 2008, 23 deaths from cardiovascular disease were recorded (2), following a national trend, since this incidence is associated with the frequency of risk factors such as Hypertension, Diabetes Mellitus and life habits as smoking, physical inactivity, obesity and stress.

The WHO (3), also emphases that regular physical activity reduces the risk of premature death, heart disease, stroke, colon cancer, breast cancer and type II diabetes, also acting in the prevention or reduction of hypertension, preventing weight gain (reducing the risk of obesity), helping to prevent or reduce osteoporosis, promoting wellness, reducing stress, anxiety and depression.

Despite the regular physical activity advantages, the prevalence of physical inactivity is very high in Brazil. A study conducted in the southeast and northeast of Brazil, showed that only 13\% of Brazilian adults practice 30 minutes of leisure physical activity at least once a week and a smaller quantity of people, $3.3 \%$ reported physical activity for 30 minutes five times a week (4).

Since the last decade, the Ministry of Health (MS) gave priority to the health promotion structure, prevention and surveillance of non-communicable diseases and disorders (DANT) as a function of the possibilities for prevention and control of these diseases (5). 
Health promotion policy suggests that actions are implemented in public health care facilities and in the community; counseling/disclosure actions; intersectoral actions and mobilization of partners and monitoring and evaluation actions. The strategies and health promotion, prevention and DANT control are currently one of the biggest challenges for the healthcare area.

Although the international and national literature related to physical activity epidemiology have grown in recent years, studies based on small and medium-sized cities are still scarce in Brazil, especially when it comes to work involving intervention in the community.

Baretta et al. (6) identified that $57.4 \%$ of adults in Joaçaba (SC) were physically inactive and Hallal et al. (7) estimated in $41.1 \%$ in Pelotas. In the northeast, Pitanga and Lessa (8) in the city of Salvador (BA) found that $72.5 \%$ of adults were sedentary (8), similar findings found $116 \mathrm{~km}$ far from the capital, in the city of Feira de Santana (BA) found prevalence of physical inactivity among adults of $72.7 \%$ (9).

In this sense, the purpose of this study is to analyze the effectiveness of an action guided by physical activity practices within the Unified Health System [Sistema Único de Saúde - SUS] in health status indicators of Family Health Strategy (FHS) users in Iguaí city, Bahia.

\section{Methodology}

Study type

The study is characterized as intervention and will have an epidemiological approach in community studies (10).

\section{Study scenario}

The city of Iguaí is located $497 \mathrm{~km}$ from Salvador, borders with Poções, Boa Nova, Dário Meira, Nova Canaã e Ibicuí. Its territory has $833 \mathrm{~km}^{2}$. Its population, estimated in 2009 (11), has 29,449 inhabitants. It is located in Vitória da Conquista micro-region, in the valley of Gongogi, river basin of Contas, between the regions of the Atlantic Forest, on the slopes of Planalto da Conquista.
Family Health Strategy coverage in Iguaí is 70.29\% of the population. Currently the city has six Family Health teams and one Family Health Center.

The study setting was the Family Health Unit 03 (USF 03) assisting 4,514 users, 553 of them are $\geq 60$ years old.

Study population

There were 85 users over 40 years old with hypertension and/or diabetes registered at USF 03. The individuals with the following conditions were excluded from the study: age less than 60 years old and those with normal BMI and minimum frequency of $85 \%$ in the sessions. After this step, the sample consisted of 30 users.

\section{Data collection technics and instruments}

The instrument had sociodemographic information, level of physical activity (International Physical Activity Questionnaire), and evaluation of blood pressure and glycemic index of weight and height for subsequent calculation of Body Mass Index (BMI).

Blood pressure was measured with a $\mathrm{BIC}^{\mathrm{TM}}$ sphygmomanometer and stethoscope, according to the recommendations of the Ministry of Health (1).

Arterial hypertension is defined as systolic blood pressure more or equal to $140 \mathrm{mmHg}$ and a diastolic blood pressure more or equal to $90 \mathrm{mmHg}$, in individuals who are not using antihypertensive medication (1).

Blood glucose monitoring was performed by a nursing technician, with digital glucometer (AccuChek Advantage II), lancets, graded from 1 to 3 in increasing degree of penetration depth (depth: $1=$ less, 2 = average, 3 = greater). The measurements were performed on the distal phalanx of the $3^{\text {rd }}$ finger of the right hand, in fasting, after collecting the blood on the glucometer; the puncture site was obstructed with cotton promoting hemostasis and checking the value calculated by the glucometer (12).

According to the Ministry of Health (3), the blood glucose levels measured in fasting are normal up to $110 \mathrm{mmHg}$.

The body weight and height evaluation were obtained with individuals wearing light clothes without shoes, by mechanical anthropometric scale. The Body 
Mass Index (BMI) was calculated by dividing weight by height squared $\left(\mathrm{kg} / \mathrm{m}^{2}\right)$. Waist circumference (in $\mathrm{cm}$ ) was obtained at the navel.

The evaluation of the physical activity level was performed using the International Physical Activity Questionnaire (IPAQ), prepared by researchers from several countries with support from the World Health Organization (13), as part of a multicenter study involving 12 countries, to know the classification of the population about physical activity (14). Each participating country has adapted and validated their questionnaire, taking into account the characteristics of the population. In Brazil, this questionnaire was validated by the Laboratory of Physical Fitness Center of São Caetano do Sul (15).

Data collection was through personal interview in outpatient consultation applying the questionnaire that assessed the frequency in days, and the duration in minutes of the activities performed more than ten continuous minutes during a normal week.

The physical activity program was conducted during 10 months, with a frequency of 5 days/week. The activities were carried out in Dr. Jailton Matos USF. The physical activity program consisted of daily walking, with low intensity based on Borg scale during the first 10 minutes. This scale proposed by Gunnar Borg ranges from 6 to 20 and in exercise intensity verification, Matsudo and Matsudo (16) recommend levels between 12-13. Then there were aerobic activities 2 times a week, involving dancing, resistance exercising performed working different muscles as quadriceps, gluteus, biceps femurs, with $1 \mathrm{~kg}$ in the form of circuit, with 10-20 series reps and exercises of the lower limbs involving chest, biceps, triceps and trapezius, with load $1 / 2 \mathrm{~kg}$. The flexibility exercises were developed at the beginning and end of the session every day during 5 minutes.

Recreational activities were developed in holidays such as St. John, with forro music, Senior's Day with group dynamics, Christmas going to a resort and conducting secret friend game, Carnival with mask dancing and Easter. In addition, birthdays were celebrated bimonthly.

\section{Ethic issues}

Data collection was performed after approval and consent of the participants, participants were interviewed individually through the research form and evaluated, and then the physical activity program began in compliance with Resolution 196/96 which deals with research on human beings. The research protocols were approved by the Ethics Committee of the State University of Southwest Bahia (195/2010).

\section{Data analysis and tables}

The data from this study were tabulated and analyzed using two computer tools through the statistical package SPSS 15.0. In the data analysis, procedures of descriptive statistics were used (average, standard deviation) and inferential with variance analysis measures (ANOVA followed by Scheffe Post Hoc) with $\mathrm{p} \leq 0.05$.

\section{Results and discussion}

Buss (17) points out that during the debate on health promotion and quality of life, healthy public policies must be strengthen, characterized as concrete operational mechanisms for the implementation of health promotion strategy and quality of life. In this sense, the result of a health promotion intervention and quality of life is presented, based on body practices to users of the Family Health Strategy.

There were 30 participants with an average of 65 years old $(\mathrm{SD}=4.4)$, with a predominance of female participants (96.7\%). As observed on the data obtained, when the project started, the participants had an average systolic blood pressure of 167.3 $\mathrm{mmHg}$ (Table 1) and the diastolic pressure of 98 mmHg (Table 2). After participating in developed body practices, the elderly had an average systolic pressure of $120 \mathrm{mmHg}$ and diastolic blood pressure of $78.3 \mathrm{mmHg}$, but the association was statistically significant only for systolic pressure $(\mathrm{p} \leq 0.05)$.

Lima et al. (18) when evaluated the effectiveness of aerobic exercise to control blood pressure in hypertensive postmenopausal women found similar results.

Hypertension is one of the most prevalent diseases in adult population and especially in the elderly and is directly related to increased morbidity and mortality in these populations (19). The exercise programs has an important role in preventing hypertension and in lowering blood pressure in both normotensive and hypertensive patients. This reduction is approximately 18 to $20 \mathrm{mmHg}$ for systolic blood pressure and 7-9 $\mathrm{mmHg}$ for diastolic blood 
Table 1 - Systolic blood pressure scores of ESF users before and after an intervention program in SUS, Iguaí, $2010(n=30)$

\begin{tabular}{lcccc}
\hline & $\begin{array}{c}\text { Minimum } \\
\text { value }\end{array}$ & $\begin{array}{c}\text { Maximum } \\
\text { value }\end{array}$ & Average & SD \\
\hline $\begin{array}{l}\text { Systolic } \\
\text { before }\end{array}$ & 130 & 230 & 167.33 & 23.228 \\
$\begin{array}{l}\text { Systolic } \\
\text { after }\end{array}$ & 90 & 150 & 120.00 & 14.606 \\
\hline
\end{tabular}

Note: $F=4.48 ; p=0.003$.

Table 2 - Diastolic blood pressure scores of ESF users before and after an intervention program in the SUS, Iguaí, $2010(n=30)$

\begin{tabular}{lcccc}
\hline & $\begin{array}{c}\text { Minimum } \\
\text { value }\end{array}$ & $\begin{array}{c}\text { Maximum } \\
\text { value }\end{array}$ & Average & SD \\
\hline $\begin{array}{l}\text { Diastolic } \\
\text { before }\end{array}$ & 80 & 120 & 98.00 & 9.092 \\
$\begin{array}{l}\text { Diastolic } \\
\text { after }\end{array}$ & 60 & 90 & 78.33 & 7.782 \\
\hline
\end{tabular}

Note: $\mathrm{F}=0.492 ; \mathrm{p}=0.742$.

pressure in hypertensive individuals and decreasing 8-10 $\mathrm{mmHg}$ and 3-5 mm for systolic and diastolic, respectively, in normotensive (20).

Study of 109 hypertensive patients in stages I and II, undergoing a light training for eight weeks in gyms, found that there was a significant reduction in blood pressure in all of them, and the elderly showed lower reduction in blood pressure that young individuals (21). This fact can be explained by structural and functional changes in the heart and vessels, and changes in the autonomic nervous system that accompany aging $(22,23)$, physical activity being even more important in this population.

The results of the study by Silva et al. (24) highlighted the value of physical activity in achieving a better quality of life. This contribution occurs, since it minimizes the degeneration caused by aging and stimulates the essential body functions.

Regular physical activity practice retains higher levels of functional capacity and especially in the cardiovascular function $(25,26,27)$, reducing anxiety, stress, contributing to the improvement of sleep disorder, invigorating the energy and providing wellbeing and quality of life for its practitioners, working in the prevention and treatment of psychological morbidity $(28,29)$.

Regarding the glycemic index among the studied elderly, there was a significant reduction in the average of blood glucose in the pre-intervention and post-intervention, from $133.9 \mathrm{mgdL}$ to $100.5 \mathrm{mgdL}$, respectively (Table 3 ).

Diabetes mellitus is one of the public health problem diseases by the high prevalence in the world and higher among the elderly, by the morbidity and for being one of the main cardiovascular and cerebrovascular risk factors (30).

The beneficial effect of exercising for health is related to the ability to fight diabetes by increasing the sensitivity of cells to insulin and by stimulating the metabolism of carbohydrates (31).

Study by Silva and Lima (32) found chronic blood glucose reduction by a regular exercise program, and states that individuals with type 2 diabetes mellitus (DM2) have their blood glucose decreased by acute effect of physical exercise, shown in glucose hair, which was collected before and after workout. Thus, he demonstrates the importance of physical activity also in the control of metabolic diseases.

The anthropometric evaluation of BMI showed that elderly have a high prevalence of overweight/ obesity before the intervention program. After the program, there was a significant reduction in BMI of the participants, as shown in Table 4. The study by Silva and Lima (32) demonstrated that the effect of physical exercise program in BMI was significant, leading to a slight decrease of $0.65 \mathrm{~kg} / \mathrm{m}^{2}$ in average BMI in the group.

Overweight and obesity are important public health problems, because besides being related to

Table 3 - Glycemic index of ESF users before and after an intervention program in SUS, Iguaí, $2010(n=30)$

\begin{tabular}{lcccc}
\hline & $\begin{array}{c}\text { Minimum } \\
\text { value }\end{array}$ & $\begin{array}{c}\text { Maximum } \\
\text { value }\end{array}$ & Average & SD \\
\hline $\begin{array}{l}\text { Glycemic } \\
\text { before }\end{array}$ & 83 & 309 & 133.87 & 46.199 \\
$\begin{array}{l}\text { Glycemic } \\
\text { after }\end{array}$ & 69 & 167 & 100.47 & 23.906 \\
\hline
\end{tabular}

Note: $F=6.910 ; p=0.012$. 
a number of chronic diseases, its gradual increase occurs continuously from childhood to adulthood, and in recent years a major challenge for researchers and health professionals (33). The physical exercise has proven an important factor in the prevention and control of overweight and obesity (34).

Table 4 - Body Mass Index (BMI) of ESF users before and after an intervention program in SUS, Iguaí, 2010 $(\mathrm{n}=30)$

\begin{tabular}{lcccc}
\hline & $\begin{array}{c}\text { Minimum } \\
\text { value }\end{array}$ & $\begin{array}{c}\text { Maximum } \\
\text { value }\end{array}$ & Average & SD \\
\hline $\begin{array}{l}\text { BMI } \\
\text { before }\end{array}$ & 25 & 38 & 28.97 & 3.306 \\
$\begin{array}{l}\text { BMI } \\
\text { after }\end{array}$ & 23 & 35 & 27.87 & 3.263 \\
\hline
\end{tabular}

Note: $\mathrm{F}=7.66 \mathrm{p}<0.001$.

Physical activity facilitates the performance of activities of daily living (functional capacity), reduces the frequency of chronic venous diseases responsible for the significant decline in labor productivity, generating retirement or disability, and restricting the activities of daily living and leisure (35) also influencing the treatment and prevention of diseases, providing an improvement of general well-being (17).

The proposed intervention covers aspects of modern health promotion, in healthy lifestyle and a suitable spectrum of health care (36), not taking into account only the individual but the collective.

Increased access to the population to physical activity programs within the primary care becomes an important strategy. The Brazilian health system through the Unified Health System (SUS) provides citizens with universal access to health services and $70-75 \%$ of the population, approximately, have access to health care, mainly through the Health Strategy family. This broad access is fertile ground for implementation of physical activity and other non-medicinal practices health care programs.

The Ministry of Health has advanced, offering financial options for specific programs (such as Corporal Practices Project of coping with diseases and non-communicable diseases, which was the object of this study) and programs with the possibility of continuity such as health clubs.

It is observed that the promotion of physical activity has become a government priority in the country. Since the health promotion policy in 2006, cities have been encouraged to develop physical activity interventions (36).

Funding was an important aspect for the success of this intervention, the resources by the Ministry of Health helped hiring physical education teachers and the purchase of materials for the execution of project's activities. The possibility of expanding the family health team, with professional incorporation with specific training for the development of physical activity programs favors the implementation, as identified by Florindo et al. (36) that the minimum professional team of family health in Brazil has a very superficial knowledge about physical activity.

A negative aspect was the insufficient participation in the intervention; only 30 users were included, the requirement of funding notice of the choice program of direct actions for users with chronic diseases (for the city studied the diseases were diabetes and hypertension), the schedules of activities were limiting factors of the expansion of the project's to a larger number of users. It is speculated that the popular mobilization observed during the intervention and the empowerment of participating users with in the understanding of the importance of physical activity is an aspect that can contribute to the expansion and continuation of the program by the municipal government.

Another limitation of this study may be related to not having been constituted a control group for comparison with the group that participated in the proposed program.

However, despite the limitations, the study demonstrated the importance of developing physical activity intervention programs in the populations assisted by the Family Health Strategy, emphasizing its contribution as non-medication treatment modality for hypertension and diabetes.

\section{Final considerations}

One of the current projects of the Ministry of Health is to insert the physical activity in the primary care network daily. Some initiatives, such as 
the project "Strategic actions of physical activity as non-medication therapy modality in prevention and control of patients with hypertension and diabetes in the city of Iguaí-Bahia", indicates that such integration may be useful for decreasing the morbidity resulting from DANTs in the population.

Although it is recommended that physical activity is important for health, prescription of physical activity by health professionals of these units is still insufficient to promote changes in the attitude of people in relation to physical activity. It can be also concluded that the USFs are not meeting the needs of users in relation to physical activity as a health promotion tool.

The progress of prevention work is being viewed. It was possible to change the habit of a group of sedentary people, but it is necessary that the projects have sustainability to continue with its development, since other results will be observed in long-term, such as the reduction of hospitalizations for chronic complications of hypertension and diabetes and it is also necessary to spread to all the Family Health Units, involving the community.

\section{References}

1. Brasil. Ministério da Saúde. Secretaria de Atenção à Saúde. Departamento de Atenção Básica. Hipertensão arterial sistêmica para o Sistema Único de Saúde. Brasília: Ministério da Saúde; 2006.

2. Brasil. Ministério da Saúde. DATASUS. 2011 [cited 2011 July 3]. Available from: http://www2.datasus. gov.br/DATASUS/index.php

3. Brasil. Ministério da Saúde. Secretaria de Atenção à Saúde. Departamento de Atenção Básica. Diabetes Mellitus. Brasília: Ministério da Saúde; 2006.

4. Monteiro CA, Conde WL, Matsudo SM, Matsudo VR, Bonseñor IS, Lotufo PAA. Descriptive epidemiology of leisure-time physical activity in Brazil, 1996-1997. Rev Panam Salud Publica. 2003;14(4):246-54.

5. Malta DC, Cezário AC, de Moura L, de Morais Neto OL, da Silva Junior JB. A construção da vigilância e prevenção das doenças crônicas e agravos não transmissíveis no contexto do Sistema Único de Saúde. Epidemiol Serv Saúde. 2006;15(3):47-65.
6. Baretta E, Baretta M, Peres KG. Nível de atividade física e fatores associados em adultos no Município de Joaçaba, Santa Catarina, Brasil. Cad Saúde Publica. 2007;23(7):1595-602.

7. Hallal PC, Victora CG, Wells JCK, Lima RC. Physical inactivity: prevalence and associated variables in Brazilian adults. Med Sci Sports Exerc. 2003;35(11):1894-900.

8. Pitanga FJG, Lessa I. Prevalência e fatores associados ao sedentarismo no lazer em adultos. Cad Saúde Pública. 2005;21(3):870-7.

9. Rocha, SV, de Almeida MMG, de Araújo TM, Virtuoso Junior JS. Fatores associados à atividade física no lazer entre residentes de áreas urbanas de um município do nordeste do Brasil. Rev Bras Cineantropom Desempenho Hum. 2011;13(4):257-64.

10. Medronho RA, Medronho RA, Bloch KV, Luiz RR, Werneck GL. Epidemiologia. 2. ed. São Paulo: Atheneu; 2009.

11. Instituto Brasileiro de Geografia e Estatística. Censo demográfico. Brasília: IBGE; 2009.

12. Ferraz DP, Maia FFR, Araújo LR. Glicemia capilar em ponta do dedo versus lóbulo de orelha: estudo comparativo dos valores resultantes e preferências dos pacientes. Arq Bras Endocrinol Metab. 2004;48(3): 389-93.

13. World Health Organization. The world report 1998: life in the 21st century - a vision for all. Geneva: WHO; 1998.

14. Craig CL, Marshall AL, Sjöström M, Bauman AE, Booth ML, Ainsworth BE, et al. International Physical Activity Questionnaire: 12-country reliability and validity. Med Sci Sports Exerc. 2003;35(8):1381-95.

15. Pardini R, Matsudo SM, Araújo T, Matsudo V, Andrade E, Braggion $\mathrm{G}$, et al. Validação do questionário internacional de nível de atividade física (IPAQ - versão 6): estudo piloto em adultos jovens brasileiros. Rev Bras Ciên e Mov. 2001;9(3):45-51.

16. Matsudo SMM, Matsudo VKR. Prescrição de exercícios e benefícios da atividade física na terceira idade. Rev Bras Ciên e Mov. 1992;5(4):19-30.

17. Lima MMO, Britto RR, Baião EA, Alves GS, Abreu CDG, Parreira VF. Exercício aeróbico no controle da hipertensão arterial na pós-menopausa. Fisioter Mov. 2011; 24(1):23-31. 
18. Barroso WKS, Jardim PCBV, Vitorino PV, Bittencourt A, Miquetichuc F. Influência da atividade física programada na pressão arterial de idosos hipertensos sob tratamento não-farmacológico. Rev Assoc Med Bras. 2008;54(4):328-33.

19. Kenney MJ, Seals DR. Postexercise hypotension. Key features, mechanisms and clinical significance. Hypertension. 1993;22(5):653-64.

20. Ishikawa HO, Ayukawa T, Nakayama M, Higashi S, Kamiyama S, Nishihara S, et al. Two pathways for importing GDP-fucose into the endoplasmic reticulum lumen function redundantly in the 0 -fucosylation of Notch in Drosophila. J Biol Chem. 2011;285(6):4122-9.

21. Cheitlin MD. Cardiovascular physiology-changes with aging. Am J Geriatr Cardiol. 2003;12(1):9-13.

22. O’Rourke MF, Hashimoto J. Mechanical factors in arterial aging: a clinical perspective. J Am Coll Cardiol. 2007;50(1):1-13.

23. da Silva EB, Krug MR, Giordani MC. Nível de atividade física e qualidade de vida dos usuários assistidos pela Estratégia de Saúde da Família do Município de Cruz Alta/RS. Revista Digital (Buenos Aires). 2010 [cited 2011, July 2];14(141). Available from: http://www. efdeportes.com/efd141/atividade-fisica-pela-estrategia-de-saude-da-familia.htm

24. Nahas MV. Atividade física, saúde e qualidade de vida: conceitos e sugestões para um estilo de vida ativo. 3. ed. Londrina: Midiograf; 2003.

25. Matsudo SM, Matsudo VKR, de Barros Neto TL.Impacto do envelhecimento nas variáveis antropométricas, neuromotoras e metabólicas da aptidão física. Rev Bras Ciên Mov. 2000;8(4):21-32.

26. Pickles B, Ann C, Janet CCS, Vander VA. Fisioterapia na terceira idade. 2. ed. São Paulo: Santos; 2000.

27. Reijneveld S, Westhof W, Hopman-Rock M. Promotion of health and physical activity improves the mental health of elderly immigrants: results of a group randomized controlled trial among Turkish immigrants in the Netherlands aged 45 and over. J Epidemiol Community Health. 2003;57(6):405-11.
28. Gerber M, Puhse U. "Dont crack under pressure!" Do leisure time physical activity and self-esteem moderate the relationship between scholl-based stress and psychosomatic complaints? J Psychosom Res. 2008;65(4):363-9.

29. Sartorelli DS, Franco LJ. Tendências do diabetes mellitus no Brasil: o papel da transição nutricional. Cad Saúde Pública. 2003;19(Suppl 1):29-36.

30. Milhomem FCH. Atividade física para prevenção e controle da hipertensão arterial em adultos. 2006;33(7/8):589-614.

31. da Silva CA, de Lima WC. Efeito benéfico do exercício físico no controle metabólico do diabetes mellitus tipo 2 à curto prazo. Arq Bras Endocrinol Metab. 2002;46(5):550-6.

32. Amer NM, Marcon SS, Santana RG. Índice de massa corporal e hipertensão arterial em indivíduos adultos no Centro-Oeste do Brasil. Arq Bras Cardiol. 2011;96(1):47-53.

33. World Health Organization. World health day 2002. Sedentary lifestyle: a global public health problem. 2002 [cited 2011, Nov 16]. Available from: http:// www.who.int/world-health-day/.

34. Júlio CP, Luciana BM. Existe associação entre doenças venosas e nível de atividade física em jovens? Fisioter Mov. 2011;24(1):147-54.

35. Buss PM. Promoção da saúde e qualidade de vida. Ciênc Saúde Coletiva. 2000;5(1):163-77.

36. Florindo AA, Mielke GI, Gomes GA, Ramos LR, Bracco MM, Parra DC, et al. Physical activity counseling in primary health care in Brazil: a national study on prevalence and associated factors. BMC Public Health. 2013;13:794.
Received: $12 / 03 / 2011$ Recebido: 03/12/2011

Approved: $10 / 20 / 2014$ Aprovado: 20/10/2014 